\title{
Effective use of Vismodegib as a neoadjuvant prior to Mohs surgery
}

Brian J Simmons BS ${ }^{1 *}$, Fleta Netter Bray BS ${ }^{1}$, Leyre A Falto-Aizpurua MD ${ }^{1}$, Mohammed Alsaidan MD ${ }^{2}$ and Keyvan Nouri MD ${ }^{1}$

${ }^{1}$ Department of Dermatology and Cutaneous Surgery, University of Miami Miller School of Medicine, Miami, USA

${ }^{2}$ Department of Dermatology, Salman bin Abdulaziz University, Riyadh, Kingdom of Saudi Arabia

\begin{abstract}
Importance: Basal Cell Carcinoma (BCC) represents a majority of skin cancers (80\%), and can be locally invasive and difficult to treat in patients with Nevoid Basal Cell Carcinoma syndrome (Gorlin syndrome) or in patients with multiple BCCs in high-risk areas.

Observations: Long-term use of Vismodegib was tolerated well in the 2 patients in this case series and was able to shrink large BCCs by up to $80.5 \%$.

Conclusions and Relevance: In Gorlin syndrome and high risk non-resectable BCCs, vismodegib can provide neoadjuvant treatment. In turn, allowing for Mohs surgery to be a viable option with smaller surgical defects with good cosmetic outcomes.
\end{abstract}

\section{Introduction}

Gorlin syndrome is an autosomal dominant disorder that usually presents with patients developing BCCs in adolescence or early adulthood. In addition, patients present with distinct faces with frontal or temporoparietal bossing, hypertelorism and mandibular prognathism. Other skeletal abnormalities can be seen along with benign odontogenickeratocyst of the jaw [1]. The condition is due to a defect in PTCH1 gene [2]. PTCH1 encodes the protein patched-1 that functions as a tumor suppressor. If the gene is mutated the cell cycle is not suppressed in turn leading to the high occurrence of BCCs.

Vismodegib acts as a competitive antagonist of the smoothened receptor part of the Sonic hedgehog-signaling pathway. In turn, leading to the inhibition of transcription factors leading to cell cycle arrest. This drug has been used in the treatment of metastatic BCCs and in controlling the occurrence of BCCs in Gorlin syndrome.

\section{Report of a case series}

\section{Case 1}

A 78-year-old Hispanic gentleman with a history of chronic sun exposure as a field worker and multiple skin cancers treated in the past including an extensive basal cell carcinoma (BCC) of the leftpostaricular with extensive involvement of auditory canal and mastoid. Patient was started on $150 \mathrm{mg} /$ day vismodegib for his extensive BCCs by oncology. Patient was seen by a dermatologist for lesions on the lower eyelids bilaterally, which were subsequently biopsied and returned the diagnosis of Morpheaform BCC. Patient was referred to our Mohs surgery clinic for evaluation and resection of cancers after being on vismodegib treatment for 13 months shrinking the tumor from $2.0 \mathrm{~cm}$ by $1.8 \mathrm{~cm}$ to $1.0 \mathrm{~cm}$ by $0.7 \mathrm{~cm}$ (Figures $1 \mathrm{a}$ and $1 \mathrm{~b}$ ). tumor was resected using traditional Mohs surgery technique in 4 stages leaving a defect of $2 \mathrm{~cm}$ by $1.6 \mathrm{~cm}$ (Figure 1c). Patient was seen by oculoplastics for surgical defect reconstruction, without complications.

\section{Case 2}

A 47-year-old Hispanic gentleman, with a previous history of Nevoid Basal Cell Carcinoma syndrome (Gorlin) with multiple family members with extensive BCCs. Patient has had a growing nodule on the nose present for 7-8 years, which started to erode and bleed easily leading the patient to present for treatment. Lesion was previously treated in Cuba via surgical excision and postoperative radiation treatment. Biopsy confirmed diagnosis of BCC nodulocystic type. Patient was started on $150 \mathrm{mg} /$ daily treatment of vismodegib and has continued treatment for approximately 3 months. Lesion shrunk from initial size of $1.5 \mathrm{~cm}$ by $1.5 \mathrm{~cm}$ to $1.2 \mathrm{~cm}$ by $1.3 \mathrm{~cm}$ (Figures $1 \mathrm{~d}$ and $1 \mathrm{e}$ ). Patient was referred for excision of lesion at our Mohs clinic where the lesion was excised using traditional Mohs technique in 1 stage leaving a $2 \mathrm{~cm}$ by $1.5 \mathrm{~cm}$ defect (Figure 1f) and was reconstructed at the Mohs surgery clinic. Patient will be followed for recurrence of BCCs on a regular basis while maintaining his vismodegib maintenance therapy for Gorlin syndrome.

\section{Discussion}

There are few studies looking at vismodegib as a neoadjuvant therapy [3-5]. This case series demonstrates that vismodegib can be used as a neoadjuvant to shrink large BCCs in patients with genetic predisposition for increased BCCs (Gorlins syndrome) and in patients with a history of locally invasive BCCs in high-risk areas. In turn, shrinking the tumors to allow for Moh's surgery with smaller defects and better reconstructive outcomes. The study by Ally et al. [5] found

Correspondence to: Brian James Simmons, Department of Dermatology and Cutaneous Surgery, University of Miami Miller School of Medicine, 1475 NW $12^{\text {th }}$ Ave. Miami, FL 33136, USA, Tel: 305-243-3996; Fax: 305-243-4184; E-mail: bjsimmons@med.miami.edu

Received: January 30, 2015; Accepted: February 13, 2015; Published: February 15,2015 


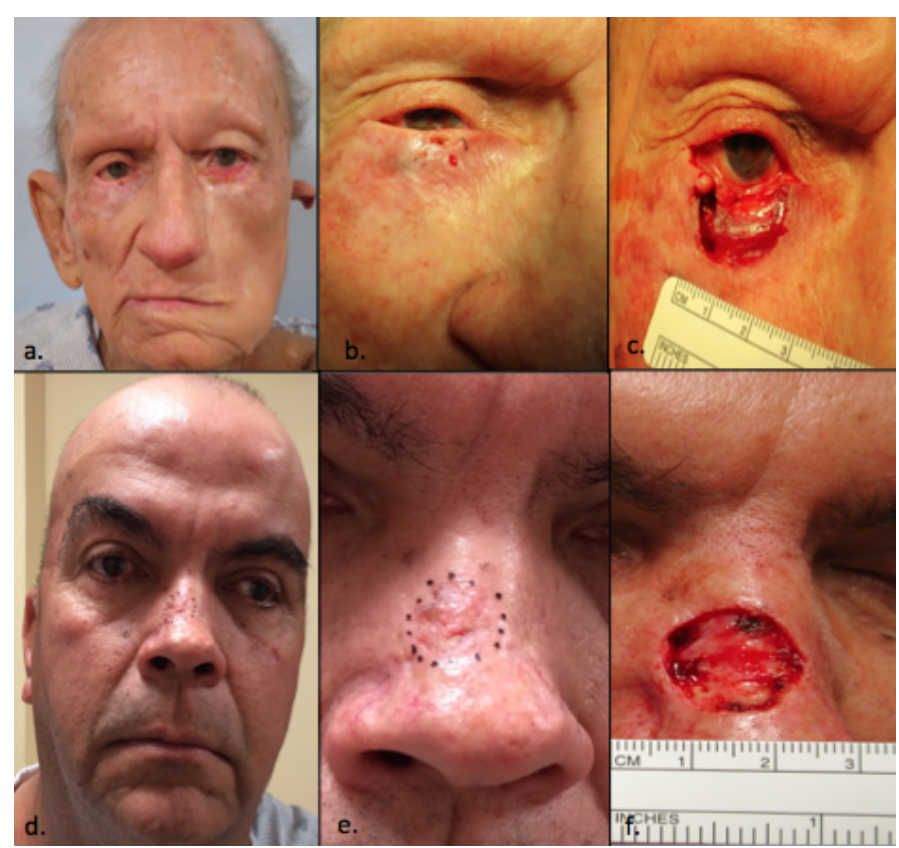

Figure 1. a. preoperative Morpheaform BCC of right lower eyelid patient 1 ; b. Close up preoperative $\mathrm{BCC}$ of right lower eyelid patient 1; c. post surgical defect after Mohs surgery patient 1; d. Preoperative Nodulocystic BCC of nasal bridge; e. Close up preoperative Nodulocystic BCC of nasal bridge patient 2; f. Post surgical defect after Mohs surgery patient 2. that surgical defects could be decreased on average $27 \%$ if at least 3 months on neoadjuvant treatment was done. Although only 2 patients were included in our case series, lesions shrunk by $80.5 \%$ and $30.7 \%$ respectively. This in turn lead to a smaller surgical defect than would have occurred with the initial untreated lesions. Thus, showing the potential for neoadjuvant vismodegib treatment for large BCCs in difficult to treat patients or in patients with genetic predispositions where recurrence is high.

\section{References}

1. Kimonis VE, Goldstein AM, Pastakia B, Yang ML, Kase R, et al. (1997) Clinical manifestations in 105 persons with nevoid basal cell carcinoma syndrome. Am J Med Genet 69: 299-308. [Crossref]

2. Johnson RL, Rothman AL, Xie J, Goodrich LV, Bare JW, et al. (1996) Human homolog of patched, a candidate gene for the basal cell nevus syndrome. Science 272: 16681671. [Crossref]

3. Chang AL, Atwood SX, Tartar DM, Oro AE (2013) Surgical excision after neoadjuvant therapy with vismodegib for a locally advanced basal cell carcinoma and resistant basal carcinomas in Gorlin syndrome. JAMA Dermatol 149: 639-641. [Crossref]

4. Aldabagh B, Yu J, Perkocha LA, Arron S (2013) Histologic changes in basal cell carcinoma after treatment with vismodegib. Dermatol Surg 39: 1703-1705.

5. Ally MS, Aasi S, Wysong A, Teng C, Anderson E, et al. (2014) An investigator-initiated open-label clinical trial of vismodegib as a neoadjuvant to surgery for high-risk basal cell carcinoma. J Am Acad Dermatol 71: 904-911. [Crossref]

Copyright: (C2015 Brian J Simmons. This is an open-access article distributed under the terms of the Creative Commons Attribution License, which permits unrestricted use, distribution, and reproduction in any medium, provided the original author and source are credited. 